\title{
Impact of Outsidered Children Status on Rights of Inheritance After Constitutional Court Decision
}

\author{
Sulaiman*) and Akhmad Khisni**) \\ ${ }^{*}$ Advocat in Kendari E-mail: udmaharani@gmail.com \\ $\left.{ }^{* *}\right)$ Lecturer of Master of Notary Law, Universitas Islam Sultan Agung (UNISSULA) \\ Semarang
}

Abstract. The objectives of this study are as follows: 1) To determine and explain the effect of the status of outsidered children status on the right to inherit after the Constitutional Court decision No. 46/PUU-VIII/2010 at the Kendari Religious Court. 2) To find out and explain the barriers to the status of outsidered children status against the right to inherit after the Constitutional Court decision No. 46/PUU-VIII/2010 at the Kendari Religious Court. 3) To find out and explain solutions to overcome the barriers to the status of children outside of marriage to the right to inherit after the Constitutional Court decision No. 46/PUU-VIII/2010 at the Kendari Religious Court. The method used by researchers is a sociological juridical legal approach and the specifications in this study include descriptive analytical. As for the sources and types of data in this study are primary data obtained from field studies with interviews with Religious Court Judges in Kendari City. And secondary data obtained from literature study. Based on the results of the research, in the case of inheritance after the decision of the constitutional court, the position of an outsidered children status as meant by the constitutional court decision of an outsidered children status is not the same as an adulterous child, has found a way or space to obtain recognition in order to protect the rights of outsidered children status. In this case the Constitutional Court ruled Article 46/PUU-VIII/2010 concerning children outside of marriage, having the right to recognition with their biological father and also entitled to an inheritance equal to the size of other children. Obstacles in this Constitutional Court Decision include the problem of the perspective of law enforcers and government officials to grant rights to children outside of marriage without different treatment or other discriminatory treatment. After providing solutions (or at least providing legal certainty) to outsidered children status born after the issuance of the Constitutional Court decision No. 46/PUU-VIII/2010 (curative), the Constitutional Court attempted with the Constitutional Court's decision to prevent the same cases from occurring.

Keywords : Impact; Status; Outsidered Children; Constitutional Court Decision.

\section{Introduction}

Children are human beings who have human values can not be eliminated by any reason. Once the importance of the child's existence in human life, then Allah made their wedding. The marriage has a purpose, among others, to reproduce (have children) is good, preserve nasab, avoid illness and create sakinah. The family wedding is an important event in human life which creates legal effect either on the relationship between the parties married it alone, or with others who have a particular interest. If the child born of the marriage, then the resulting legal relationship between a child and his parents. As a citizen of every child is entitled to grow in accordance with their nature as creatures of God. Children are entitled to education, care, guidance so that it 
becomes an adult. According to the CRC that child means every human being below the age of 18 years even Act No. 23 of 2002 on the Protection of the Child defines a child from inside the womb to better provide comprehensive protection of children. ${ }^{1}$

In contrast, children also have obligations to their parents, who provided for in Article 46 of Act No. 1 of 1974 on Marriage, the children are obliged to respect their parents and obey the will of those who are good, and if the child has grown up he is obliged to maintain according to his ability, parents and family in a straight line upwards, when they need help. This proves the existence of a legal relationship with the emergence of rights and obligations between parents and children of a Child marriage is also one of the heirs entitled to receive an inheritance. Both boys and girls are the heirs of their parents, even he is closest heir to the deceased. Inheritance relationships between parents and children is based on their relationship by blood or also called nasab relationship, because there has been a biological relationship between husband and wife in the marriage bond, and then the child was born. However, the problem here is a child born outside marriage.

Outside child children marry other than adultery and discordant child will have a civil relationship (inheritance rights) with his father and mother through recognition as stated in the Civil Code. Recognition of the child can be done in several ways like an authentic deed before marriage, along with in accomplishing the marriage, made by an employee of the civil records were registered in the register of births. ${ }^{2}$

Beyond mating child population in administrative law are also entitled to get a birth certificate as legitimate children in general, but because of the provisions of Article 43 paragraph (1) of the Marriage Law Jo. Article 100 Compilation of Islamic Law (KHI) which states that a child outside the marriage have a civil relationship with her mother and her mother's family, it has implications for the ways and mechanisms of registration of birth certificates for children outside of marriage. On the outside the child's birth certificate will mate only mentioned her name only, while the father's name will not be recorded in the birth certificate the kid. The legal relationship between the child with his biological father resulted in the father does not have the obligation anything against her, and vice versa child does not right to demand anything from the father relating to civil rights.

\section{Research Methods}

This study the juridical sociological research methods used by the author is the case study method. Provides that case studies is a strategy that is more suitable when the principal question to one study, when researchers have little opportunity to control the events that will be investigated, and where the focus of his research lies in the phenomenon of contemporary within the context of real life. ${ }^{3}$ Specifications research

\footnotetext{
${ }^{1}$ Hadikusuma, Hilman. (1995). Hukum Pernikahan Indonesia. Bandung: Mandar Maju. p. 10

${ }^{2}$ Act No. 1 of 1974 on Marriage jo. Gazette of the Republic of Indonesia 1975 No. 12, The addition in State No. 3050

${ }^{3}$ Yin, Robert K. (2008) Studi Kasus, Desain \& Metode, Issue 1, Print. 12. Jakarta: Raja Grafindo Persada. p. 37
} 
used in this study is a descriptive analysis, from this study is expected to obtain a detailed and systematic description of the problem to be studied. The analysis is meant by an idea, facts obtained will be analyzed carefully to address the problem. ${ }^{4}$ The source and type of data in this study are primary data obtained from field studies with interview Religious Court Judge in Kendari, and the secondary data obtained from the study of literature.

\section{Result and Discussion}

\subsection{Effect of Children of Outsidered Children Status against Inherited Rights after Constitutional Court Decision No. 46/PUU-VIII/2010 in the Religious Court of Kendari}

Child rights are part of human rights must be upheld and protected by parents, community, and country. Various facilities should be provided to ensure the growth and development of children in an optimal and targeted. ${ }^{5}$ The fulfillment of these rights are implemented without discrimination. ${ }^{6}$

Article 27 paragraph (1) of the 1945 Constitution requires all citizens shall be equal before the law. CRC (Convention on the Rights of the Child) also requires that every child should be respected and guaranteed their rights without discrimination in any form without regarded to race, color, sex, language, religion, creed, race, ethnicity, wealth, birth or other position of the child or the child's parents or caregivers are legitimate, then the rights of the child outside the mating is also guaranteed without discrimination. ${ }^{7}$

Discrimination against civil rights to children outside of marriage is not aligned with the principles of the concept of human rights. Article 1 of the Universal Declaration of Human Rights (UDHR), stated that all people are born free and have the dignity and the same rights. They are endowed with reason and conscience and should associate with one another in the fraternity. ${ }^{8}$ Article 2 states that everyone is entitled to all the rights and freedoms set forth in this Declaration, with no exceptions whatsoever, such distinction as to race, color, sex, language, religion, political or other views, national origin or social, property, birth or other position. Specifically Article 25 paragraph (2) of the Universal Declaration states that mothers and children are entitled to special care and assistance. All children, whether born in or outsidered children status, shall enjoy the same social protection. ${ }^{9}$ Declaration of Rights of the Child also requires that children should enjoy all the rights only, without discrimination because of race, color,

\footnotetext{
${ }^{4}$ Hartono, Sunaryati. (1994). Penelitian Hukum Indonesia Pada Akhir Abad ke-20. Bandung: Alumni. p. 101

${ }^{5}$ Thaib, HM Hasballah \& Iman Jauhari. (2004). Kapita Selekta Hukum Islam, Medan: Pustaka Bangsa Press. p. 5

${ }^{6}$ Alam, Andi Syamsu \& M. Fauzan. (2008). Hukum Pengangkatan Anak Perspektif Islam. Jakarta: Kencana Prenada Media Group. p. 1

${ }^{7}$ Article 1 of the UN Convention on Child Rights

${ }^{8}$ Article 1 of the Universal Declaration on Human Rights

${ }^{9}$ Djamil, Nasir. (2013). Anak Bukan untuk Dihukum: Catatan Pembahasan UU Sistem Peradilan Anak. Jakarta: Sinar Grafika. p. 26.
} 
sex, language, religion, political or other views, national origin or social, property, birth, or social status the other, both he and his family; Every child should be protected from any practice of discrimination based on racial, religious and other forms. ${ }^{10}$

Likewise, the concept of justice put forward Majid Khadduri ${ }^{11}$ where civil rights were acquired by the illegitimate child of his biological father after the Constitutional Court Decision No. 46/PUU-VIII/2010 was issued. In addition it seems fair that provides a decent living for the child not only for the child's mother and the father alone but also have obligations.

In connection with Constitutional Court Decision No. 46/PUUVIII/2010 dated 17 February 2012, in dictum reviewing the provisions of Article 43 paragraph (1) of Act No. 1 of 1974 marriage becomes;

"Children born outsidered marriage status have a civil relationship with her mother and her mother's family, and with his father as a man who can be proved by science and technology and/or other evidence according to the law have blood relations, including civil relations with his father's family."

According to $\mathrm{Mr}$. Abd. Farih, $\mathrm{SH} ., \mathrm{MH}$, as the judge in the Religious Court of Kendari ${ }^{12}$ that there is a relationship minimal legacy nasab (humanity)/fairness most part $1 / 3$ and should not be detrimental to other heirs.

Inheritance rights for children outside of marriage after the Constitutional Court Decision No.46/PUU-VIII/2010: In the case of inheritance after the court ruling, the position of a child outside of marriage as intended by the constitutional court decision outside the mating is not the same child with bastard, has been gaining street or space to get recognition for the sake of protection of the rights of the child outside the mating. Then the equation outside child marriage mate and children through legitimate rights and equal protection, the only difference being how they have the same rights and protections. In this case the Constitutional Court to decide Article 46/PUU-VIII/2010 on children outside of marriage, deserved to be recognized by the biological father and is also entitled to inheritance equal to the other children.

3.2. Barriers of Outsidered children status of the Rights of Inheriting after Constitutional Court Decision No. 46/PUU-VIII/2010 in the Religious Court of Kendari

How to calculate the absolute section should observe the provisions of Article $916 \mathrm{~A}$ of the Civil Code. Under the terms of that Article, in terms of absolute no heirs and the heirs are not absolute, it must not violate the absolute section is specified. Determination of the absolute part regardless of the heir is not absolute. Outside child heir marries absolute categorized by Constitutional Court Decision No. 46/PUU-

\footnotetext{
${ }^{10}$ Gultom, Maidin. (2012). Perlindungan Hukum Terhadap Anak dan Perempuan. Bandung: Refika Aditama. p. 103

11 Khadduri, Majid. (1999). Teologi Keadilan, Perspektif Islam, translated by H. Mochtar Zoerni. Surabaya: Risalah Gusti. p. 119-201

12 Interviews with Drs. Tahir, SH., MH, as the judge in the Religious Kendari, on December 23, 2019, 10:45 pm
} 
VIII/2010 for children outside of the mating obtain recognition of the biological father or past legal actions in court. And if it exceeds the amount the absolute part determined without taking into account the heir is not absolute, the excess can be reclaimed by the heirs of the absolute.

According to the explanation of Prof. Ali Afandi, the purpose of provisions of Article $916 \mathrm{~A}$ of the Civil Code is that the heir is not absolute protection of the heirs of the absolute. In addition, part of the legacy absolute heirs are not harmed and conducted by the heir. By not taking into account the heir is not absolute, then the absolute heir inheritance be great because of the No. of heirs is diminished, as part of the absolute calculated based on the part of an heir.

The growing absolute part means more narrow the possibility of grants. In this way, the absolute part that can not be reduced enough to at between the heirs and the heir absolute not absolute because in calculating the section on basic wear their heirs. The quantify the absolute rights in the event there is a testament to the inheritance, for example, is Heir to leave a child and a wife. Son is absolute heirs (including children outside the mating After a Constitutional Court decision) and the wife is not absolute heir. Part of the child and mother together, part of the child half the inheritance. ${ }^{13}$

Absolute part of the child is one-half times half the inheritance, equal to a quarter of the legacy. Thus, the legacy of which can be granted are all reduced inheritance legacy quarter, equal to three-quarters. Based on these calculations it is clear that the wife does not acquire any portion of inheritance because after deducting the absolute right (a quarter of a legacy) can be granted all the (three-quarters legacy). With the provisions of Article 916 of the Civil Code a state into another. Based on this article, since it is not an heir wives absolutely computed first as heir. Which is calculated only child (legitimate or outsidered children status) as heirs absolute. Putting aside the earlier wives, children receive the entire inheritance.

Thus, the absolute right of a child is one-half of all inheritance. That can be granted is one-half the remaining estate, instead of three-quarters of a legacy as the first calculation. Because that can be granted is now only half the inheritance, there is still half the inheritance to the heirs, both absolute and not absolute. Half the estate was divided between wives and children. According to Article 852 a Civil Code, section by section of the wife, children, the wife gets a quarter inheritance and child gets a quarter of its heritage.

Constraints in this Constitutional Court decision is a matter of perspective among law enforcement and government officials to give up the rights to illegitimate children are no different treatment or other discriminatory treatment.

\footnotetext{
${ }^{13}$ Book of Civil Law 2015
} 
3.3. The Solutions of Overcoming Obstacles of outsidered children status of the Rights of Inheriting Following the Ruling of the Constitutional Court No. 46/PUUVIII/2010 Religious Court of Kendari

For the author, the Constitutional Court decision No. 46/PUU-VIII/2010 is a barrier between areas of curative and preventive region. Fate of Children extramarital happened before the decision of the Constitutional Court is trying to be more protection to be given assertions about the civil rights of a child outsidered children status to her biological father in order for the government to give sanction for any man to conceive the child in the womb of the mother so as not arbitrarily left its responsibilities as the biological father of the child. Because in any religious concept, the term original sin is not known.

According to Imam Musthofa, cancellation applicability of Article 43 paragraph (1) of Act No. 1974 marriage aims: 1) Giving legal entity blood relationship between the child and her biological father, namely that the blood relationship between the child's biological father was originally just a reality of a legal relationship that has legal consequences. 2) Provide legal protection of the fundamental rights of children, both against his father and his father's family and the environment. 3) Provide equitable treatment of every child born despite marital parents are not (yet) no certainty. 4) Reaffirming their civil relationship with each child's biological father and his father's family in accordance with the law as a civil relationship with her mother and her mother's family. 5) Reaffirming their obligations under the law's father (legal custady) maintain every child born of his blood. 6) Protect children from his father's inheritance rights for their blood relations, rights and responsibilities to one another. 7) To ensure the future of children as children in general. 8) Ensure the child's right to receive the care, maintenance, education and cost of living, the others from his father as they should. 9) Give firmness law that every man should be responsible for their actions and the consequences arising from the offense, in this case led to the birth of children. They can not escape that responsibility. ${ }^{14}$

After giving a solution (or at least provide legal certainty) to a child outsidered children status who were born after the release of the decision of the Constitutional Court No. 46/PUU-VIII/2010 was (curative), the Court seeks the decision of the Court in order to prevent cases of the same does not happen again. It is not the effort of the Court to legalize adultery. But rather an effort to prevent the Court in order to prevent (or can be said to suppress) cases of the birth of a child outside of marriage, in addition to sanctioning or with language software is to give responsibility for the biological father to the survival of children (outsidered children status) it. In addition to the decision of the Court, should not merely debating things that happened before the decision of this Court decided.

\footnotetext{
${ }^{14}$ Mustafa, Imam. (2012). Dampak Putusan Mahkamah Konstitusi Mengenai Pasal 43 Ayat (1) Undang-Undang Perkawinan No 1 Tahun 1974 Terhadap Hukum Keluarga Di Indonesia, Al-Manahij: Jurnal Kajian Hukum Islam Vol. 6. No. 2. p. 291.
} 


\section{Conclusion}

Constraints in this Constitutional Court decision is a matter of perspective among law enforcement and government officials to give up the rights to illegitimate children are no different treatment or other discriminatory treatment. And after giving a solution (or at least provide legal certainty) to a child outsidered children status who were born after the release of the decision of the Constitutional Court No. 46/PUU-VIII/2010 was (curative), the Court seeks the decision of the Court in order to prevent cases of the same does not happen again. It is not the effort of the Court to legalize adultery. But rather an effort to prevent the Court in order to prevent (or can be said to suppress) cases of the birth of a child outside of marriage, in addition to sanctioning or with language software is to give responsibility for the biological father to the survival of children (outsidered children status) it. In addition to the decision of the Court, should not merely debating things that happened before the decision of this Court decided.

\section{References}

Journal:

Mustafa, Imam. (2012). Dampak Putusan Mahkamah Konstitusi Mengenai Pasal 43 Ayat (1) Undang-Undang Perkawinan No 1 Tahun 1974 Terhadap Hukum Keluarga Di Indonesia, Al-Manahij: Jurnal Kajian Hukum Islam Vol. 6. No. 2

Books:

[1] Khadduri, Majid. (1999). Teologi Keadilan, Perspektif Islam, translated by $\mathrm{H}$. Mochtar Zoerni. Surabaya: Risalah Gusti

[2] Yin, Robert K. (2008) Studi Kasus, Desain \& Metode, Issue 1, Print. 12. Jakarta: Raja Grafindo Persada

[3] Alam, Andi Syamsu \& M. Fauzan. (2008). Hukum Pengangkatan Anak Perspektif Islam. Jakarta: Kencana Prenada Media Group

[4] Djamil, Nasir. (2013). Anak Bukan untuk Dihukum: Catatan Pembahasan UU Sistem Peradilan Anak. Jakarta: Sinar Grafika

[5] Gultom, Maidin. (2012). Perlindungan Hukum Terhadap Anak dan Perempuan. Bandung: Refika Aditama

[6] Hadikusuma, Hilman. (1995). Hukum Pernikahan Indonesia. Bandung: Mandar Maju

[7] Hartono, Sunaryati. (1994). Penelitian Hukum Indonesia Pada Akhir Abad ke-20. Bandung: Alumni

[8] Thaib, HM Hasballah \& Iman Jauhari. (2004). Kapita Selekta Hukum Islam, Medan: Pustaka Bangsa Press

Regulations:

[1] Act No. 1 of 1974 on Marriage jo. Gazette of the Republic of Indonesia 1975 No. 12, The addition in State No. 3050

[2] Article 1 of the UN Convention on Child Rights

[3] Article 1 of the Universal Declaration on Human Rights

[4] Book of Civil Law 2015 
Interview:

Interviews with Drs. Tahir, SH., MH, as the judge in the Religious Kendari, on December 23, 2019, 10:45 pm 